\title{
Role of Quality of Life as Endpoint for Inflammatory Bowel Disease Treatment
}

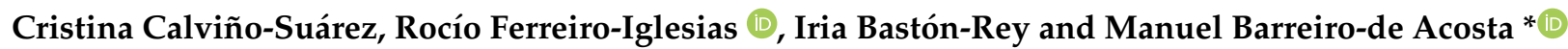 \\ IBD Unit, Gastroenterology Department, University Hospital of Santiago de Compostela, \\ 15706 Santiago de Compostela, Spain; criscalvino.su@hotmail.com (C.C.-S.); rocioferstg@hotmail.com (R.F.-I.); \\ iria.baston@gmail.com (I.B.-R.) \\ * Correspondence: manubarreiro@hotmail.com
}

Citation: Calviño-Suárez, C.; Ferreiro-Iglesias, R.; Bastón-Rey, I.; Barreiro-de Acosta, M. Role of Quality of Life as Endpoint for Inflammatory Bowel Disease Treatment. Int. J. Environ. Res. Public Health 2021, 18, 7159. https://doi.org/10.3390/ ijerph18137159

Academic Editors: Alejandro Molina-Leyva, Salvador Arias-Santiago, Eduardo Redondo Cerezo, Miguel Angel Gonzalez-Gay and Paul B. Tchounwou

Received: 5 May 2021 Accepted: 1 July 2021 Published: 4 July 2021

Publisher's Note: MDPI stays neutral with regard to jurisdictional claims in published maps and institutional affiliations.

Copyright: (c) 2021 by the authors. Licensee MDPI, Basel, Switzerland. This article is an open access article distributed under the terms and conditions of the Creative Commons Attribution (CC BY) license (https:// creativecommons.org/licenses/by/ $4.0 /)$.

\begin{abstract}
Inflammatory bowel diseases (IBDs) are chronic disabling conditions, characterized by an unpredictable course with flare-ups and periods of remission, that frequently affect young people and require lifelong medical follow-up and treatment. For years, the main endpoints of IBD treatment had been clinical remission and response, followed by biomarker normalization and mucosal healing. In the last decades, different therapies have been proved to be effective to treat IBD and the use of patient reported outcome (PRO) have become more relevant. Therefore, health-related quality of life (HRQoL) that has been defined as the value assigned to the duration of life influenced by physical and mental health, has been suggested as an important endpoint for IBD management since multiple studies have shown that IBD impairs it, both physically and psychologically. Thus, HRQoL has been included as an outcome in numerous studies evaluating different IBD therapies, both clinical trials and real-life studies. It has been assessed by using both generic and specific disease tools, and most treatments used in clinical practice have been demonstrated to improve HRQoL. The relevance of HRQoL as an endpoint for new drugs is going to increase and its management and improvement will also improve the prognosis of IBD patients.
\end{abstract}

Keywords: quality of life; Crohn's disease; ulcerative colitis

\section{Introduction}

Traditional medicine was focused on the physical side of the illness and death rates and life expectancy were the main measures used to evaluate people's health. This excludes the fact that, in most diseases, the state of health is deeply influenced by mood, coping mechanisms to different situations and social support. The higher prevalence of chronic conditions, as a consequence of the decline of infectious diseases, as well as the development of new technologies that reduced pain, have made necessary newer and more sensitive outcomes beyond morbidity and biological functioning [1]. Quality of life (QoL) has been considered as a component of health since 1947 when the World Health Organization (WHO) began to define health not only as the absence of disease, but also as a state of physical, mental and social well-being [2]. Health-related quality of life (HRQoL) has been defined as the value assigned to the duration of life influenced by health, which is modified by impairments, functional state, perceptions and opportunities that are in turn influenced by diseases, injury and treatments [3]. HRQoL only includes components that are part of an individual's health and, therefore, excludes other aspects of QoL, as political or economic factors [4].

Inflammatory bowel diseases (IBD) are chronic, progressive and disabling conditions affecting young people that have a negative impact on their HRQoL [5]. For years, the main endpoints of IBD treatment had been clinical remission and response. Afterwards, new targets like biomarkers and mucosal healing have been introduced in new drug evaluations and, in the last decades, the use of patient-reported outcome (PRO) has also become especially important. In 2015 the Selecting Therapeutic Targets in Inflammatory 
Bowel Disease (STRIDE) program was initiated by the International Organization for the Study of Inflammatory Bowel Diseases (IOIBD). It examined potential treatment targets for IBD to be used for a "treat-to-target" clinical management strategy using an evidence-based expert consensus process. In these first recommendations, improvement of HRQoL was only suggested as part of PRO [6]. In the recently published STRIDE II consensus, HRQoL has more weight and it is recommended as an important endpoint for IBD management [7].

\section{How Can We Measure HRQoL in IBD?}

There are two main types of HRQoL tools to evaluate patients with IBD: diseasespecific and generic. Disease-specific tools evaluate symptoms and compare the effect of different treatments, while generic tools allow for comparisons between different population and illnesses.

It is important to take into account two psychometric considerations for choosing which instrument to measure HRQoL:

- Reliability is the probability that a questionnaire will perform its intended function adequately. A reliable measure is one that provides consistent and accurate information.

- Validity is how accurately a method measures what it is intended to measure. A tool is valid when it measures the characteristic that it claims to measure.

Plenty of IBD-specific HRQoL tools have been developed and validated for IBD patients [8]. Nevertheless, the majority of these instruments have had no patient involvement in their development [9]. In Table 1, we summarize the main characteristics of the most widely used tools and some other options designed for specific IBD cohorts.

Table 1. Characteristics of tools for measure HRQoL in IBD.

\begin{tabular}{|c|c|c|c|c|c|c|c|}
\hline & & Target & $\begin{array}{l}\text { Recall } \\
\text { Period }\end{array}$ & $\begin{array}{l}\text { Number } \\
\text { of Items }\end{array}$ & $\begin{array}{l}\text { Response } \\
\text { Options }\end{array}$ & $\begin{array}{l}\text { Range of Scores } \\
\text { (Worst-Best) }\end{array}$ & Reliability \\
\hline \multirow{8}{*}{ 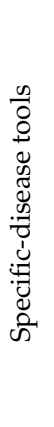 } & IBDQ-32 & IBD & 2 weeks & 32 & 7-Level Likert (1-7) & $32-224$ & +++ \\
\hline & SIBDQ & IBD & 2 weeks & 10 & 7-Level Likert (1-7) & $10-70$ & ++ \\
\hline & IBDQ-36 & IBD & 2 weeks & 36 & 7-Level Likert (1-7) & $36-252$ & NA \\
\hline & IBDQ-9 & IBD & 2 weeks & 9 & 7-Level Likert (1-7) & $0-100$ & ++ \\
\hline & CUCQ-8 & IBD & 2 weeks & 8 & $\begin{array}{l}\text { 4-Level Likert }(0-3) \text { or } \\
\text { ordinal format }(0-14)\end{array}$ & $90-0$ & +++ \\
\hline & CLIQ & $\mathrm{CD}$ & Today & 27 & True/Not true (1-0) & $27-0$ & +++ \\
\hline & IBDQ-D & UC-IPAA & 2 weeks & 32 & 7-Level Likert (1-7) & $32-224$ & NA \\
\hline & CAF-QoL & CD & $6-8$ weeks & 28 & 4-Level Likert (0-4) & $112-0$ & +++ \\
\hline \multirow{2}{*}{ 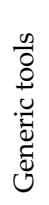 } & SF-36 & $\begin{array}{c}\text { Patients and } \\
\text { general population }\end{array}$ & 4 weeks & 36 & $\begin{array}{l}\text { Linear transformation of } \\
\text { raw scores }\end{array}$ & $0-100$ & +++ \\
\hline & EQ-5D & $\begin{array}{c}\text { Patients and } \\
\text { general population }\end{array}$ & Today & 6 & $\begin{array}{l}\text { - 3-Likert (1-3) } \\
-5 \text {-Likert (1-5) } \\
\text { - visual analogue scale }\end{array}$ & $\begin{array}{l}243 \text { health status, index } 0-1 \\
-0-100\end{array}$ & +++ \\
\hline
\end{tabular}

+ Poor, ++ Fair, +++ Good

The Inflammatory Bowel Disease Questionnaire 32 (IBDQ-32) and Inflammatory Bowel Disease Questionnaire 36 (IBDQ-36) are the most commonly used [10]. IBDQ-32 is a 32-item questionnaire that has been demonstrated to be reliable and valid. It includes four aspects of the patients' life and the main domains are intestinal symptoms (10 items), systemic symptoms (five items), social (12 items) and emotional domains (five items). Häuser et al. conducted a validation study of the German version of the IBDQ (IBDQ-D) for patients with ileal pouch anal anastomosis (IPAA) for UC, and they observed that it was a reliable tool in this setting although it had some limitations in terms of validity [11]. The short version of IBDQ-32 is the Short Inflammatory Bowel Disease Questionnaire (SIBDQ). SIBDQ also contains symptom, social and emotional sections. IBDQ-36 is a 36item questionnaire that has also been proven to be valid and reliable. It comprises the 
following points: intestinal symptoms (eight items), systemic symptoms (seven items), social (6 items) and emotional domains (eight items), and functional impairment (seven items). The short version of IBDQ-36 is IBDQ9. IBDQ9 only contains one domain (total score) and the comprehensiveness is lower than IBDQ-36 [9].

Another tool, Crohn's Life Impact Questionnaire (CLIQ), composed of 27 dichotomous items, is focused on how the impairments affect need fulfilment. It has demonstrated good validity and reproducibility, and it is easy to complete in a few minutes [12]. Recently, the Crohn's Anal Fistula Quality of Life (CAF-QoL) has been developed to evaluate the impact of anal fistula. It is a new PRO measure for Crohn's perianal fistula that has been validated. CAF-QoL is a 28-item questionnaire that has demonstrated to be internally consistent, reliable, stable and valid [13]. Among them, the best questionnaires related to relevance, comprehensiveness and comprehensibility are IBDQ-32 and CLIQ. In Table 1, we summarize the main characteristics of the most widely questionnaires used.

Other examples of disease-specific instruments are the Crohn's and Ulcerative Colitis Questionnaire (CUCQ), Inflammatory Bowel Disease Questionnaire 30 (IBDQ-30), Norwegian Inflammatory Bowel Disease Questionnaire (IBDQ-N), Cleveland Global Quality of Life (CGQL), Short Health Scale (SHS), Edinburgh Inflammatory Bowel Disease Questionnaire (EIBDQ), short Inflammatory Bowel Disease Questionnaire 10 (sIBDQ-10) and Inflammatory Bowel Disease Disability Index (IBD-DI). In paediatric IBD patients, the IMPACT series tools (IMPACT, IMPCT-II and IMPACT III) were used to evaluate the HRQoL. IMPACT was proven to be valid and contains 4 domains: symptoms, physical, emotional and social domains $[8,14]$.

The generic questionnaires most commonly used are the Generic 36-item Short Form Survey (SF-36) and The EuroQoL-dimension (EQ-5D). SF-36 was developed in the USA for use in the Medical Outcomes Study (MOS). It is a generic scale that provides quantitative information related to HRQoL and has good validity and reliability. It is frequently reported as two separate figures, a physical component score (PCS) and a mental component score (MCS), which included a total of 36 items allocated in eight domains: physical functioning (10 items), role physical (four items), social functioning (two items), bodily pain (two items), mental health (five items), role emotional (three items), general health perceptions (five items) and one item about general health [15]. EQ-5D is a generic, reliable and valid instrument developed by the EuroQoL group. It can be used to assess HRQoL but also the cost-utility analysis of health care interventions [16]. Other similar instruments can be World Health Organization Quality of Life (WHOQOL)-BREF, Short Form SF-12, Satisfaction with Life Scale (SWLS), EORTC Quality of Life Questionnaire C-30, Quality of Well Being Scale or Health Utilities Index $[17,18]$. In paediatrics, the generic tools more widely used are PedsQ1, Child Health Questionnaire (CHQ), KINDL, KINSCREEN 27, DISABKIDS HRQOL [19].

\section{Quality of Life Studies in UC}

To date, multiple studies have reported that UC impairs QoL, which can also be affected by demographic, psychological and socioeconomic factors [20,21]. Clinical activity was pointed out as the factor with the most negative impact in HRQoL [22], although it has been shown that it's still compromised during quiescent disease as compared to the general population [23]. Rasmussen et al. observed that bowel frequency, urgency and rectal bleeding are the symptoms that most significantly affect these patients' HRQoL [24]. Apart from the physical symptoms, IBD patients complain about an important emotional burden which is barely addressed during follow-up appointments [25,26]. Different therapies have been proved to be effective to treat UC and improve the HRQoL of those who suffer from it (Table 2) although its administration schedules and side effects can also negatively affect HRQoL.

Since the 1990s, several studies were conducted to assess the effect of 5-ASAs in UC patients HRQoL. Back then, Robinson et al. published a randomized, double-blind, multicentre trial which included $374 \mathrm{UC}$ patients under oral mesalamine $1 \mathrm{~g}$, $2 \mathrm{~g}$ or $4 \mathrm{~g}$ 
daily versus placebo. They evaluated twelve HRQoL parameters (five symptoms and seven aspects of general life) and observed a significant improvement of all of them in $2 \mathrm{~g}$ and $4 \mathrm{~g}$ daily mesalamine groups versus placebo [27]. Probert et al. undertook a clinical trial where 127 patients with extensive mild-to-moderately active UC were randomized to a combined oral and rectal mesalazine or oral mesalazine with rectal placebo. The EQ-5 D questionnaire was used to evaluate HRQoL at 2, 4 and 8 weeks. Although there were no differences between both groups at baseline and 8 weeks, they observed significant improvements at week 4 in the combination therapy group in 'morbidity', 'usual activity' and 'anxiety/depression' domains, which reflects a quicker efficacy of combined oral and rectal treatment [28].

Only a few studies have been undertaken to evaluate the impact of corticosteroids in UC patients' HRQoL. In an IBD cohort study, the IBSEN study group didn't encounter any significant difference between UC patients treated with corticosteroids compared to non-users after a five-year disease course [29]. However, seven years later, the same group observed that the use of corticosteroids leads to a worsening HRQoL in UC patients [20]. On the same line, corticosteroids were pointed out as the only treatment between the top ten factors with the strongest impact on HRQoL [30].

The evidence on the effect of immunomodulators in UC patients' HRQoL is scarce. Neither has any difference been found between azathioprine users and non-users in terms of HRQoL in previously mentioned UC group of the Norwegian cohort [29]. Nonetheless, this drug has been associated with a HRQoL improvement in an English IBD patients survey from 2007 [31] and a more recent Saudi IBD cohort study, whereby those patients treated with azathioprine registered higher EQ-5D scores ( $\beta=9.35$; 95\% CI: 0.486-18.22; $p=0.003$ ) [32].

Several studies have reported the biological treatments' influence on UC patients' HRQoL. As infliximab was the first biological therapy approved for UC in 2005, the ACT 1 and ACT 2 were the first trials demonstrating higher IBDQ scores from those patients treated with 5 or $10 \mathrm{mg} / \mathrm{kg}$ of infliximab when compared to placebo at week 8 (mean score of 40, 36 and 28, respectively; $p<0.001$ ). Patients on infliximab maintenance therapy kept this HRQoL improvement at weeks 30 and 54, also observed on the SF-36 score [33]. Recently, it has been shown that infliximab still improves UC patients' HRQoL in a prospective study in which a significant change of IBDQ score was seen from 116.20 at baseline to 176.62 at week $54(p=0.02)$ [34].

In 2012, adalimumab was proved to be effective as an induction and maintenance treatment for UC in the ULTRA 1 and ULTRA 2 trials, and it has also been associated with a better HRQoL among anti-TNF $\alpha$ naïve patients in comparison to placebo at weeks 8 (mean IBDQ score of 48 vs. 31, $p=0.039$ ) and 52 (mean IBDQ score 102 vs. 75, $p=0.004$ ) [35]. Afterwards, these results would be confirmed in real-life studies as in the InspirADA study whereby patients with moderate to severe UC on adalimumab reported a significant improvement in their HRQoL, which was assessed by the SIBDQ (mean change \pm SD: $17.4 \pm 14.5$ ) and the EQ-5D (index: $0.1 \pm 0.2$; VAS $19.5 \pm 25.8$ ) [36].

In a post-hoc analysis from PURSUIT-SC induction trial, the highest HRQoL scores at week 6 were communicated by golimumab treated patients when compared to placebo (IBDQ 27.2 vs. 14.6, $p<0.001$; SF-36 PCS 4.14 vs. 2.46 and MCS 4.89 vs. $1.60, p<0.01$ for both comparisons). There haven't been any significant differences found in the mean mentioned HRQoL scores between the two doses of golimumab (400/200 mg vs. 200/100 mg) [37].

Apart from anti-TNF $\alpha$, vedolizumab and ustekinumab have also proved to be effective for improving UC patients' HRQoL. Results from the GEMINI 1 trial revealed a significant improvement on IBDQ and EQ-5D scores on vedolizumab every 8 or 4 weeks as compared to placebo at week 52 (IBDQ mean difference $\geq 21.1$ and EQ-5D mean difference $\geq 9.3$ for both vedolizumab groups). However, this significant difference on EQ-5D was just detected on the vedolizumab every 4 weeks group [38]. Recently, the VARSITY trial, the first head-to-head trial comparing biological treatments for UC, reported results (mean IBDQ score $\pm S D$ ) in favor to vedolizumab in terms of HRQoL improvement at week 30 
$(61.3 \pm 39.8$ vs. $52.6 \pm 42.8)$ and 52 (66.1 \pm 41.8 vs. $60.4 \pm 42.2)$ [39]. On the other hand, UNIFI trial showed that ustekinumab raises the HRQoL after induction in comparison with placebo, and this benefit was sustained at week 44 [40] and 92 on the long-term extension study on which $55.6 \%$ of patients who had been treated with ustekinumab were in IBDQ remission [41].

Tofacitinib is the first small molecule approved as a treatment for UC and it also has been shown to achieve greater changes in IBDQ and SF-36 scores versus placebo. In OCTAVE induction 1 and 2, mean IBDQ changes from baseline to week 8 was 40.7 and 44.6 with tofacitinib $10 \mathrm{mg}$ twice daily versus 21 and 25 with placebo, respectively $(p<0.001)$. Mean SF-36 changes were comparable with the IBDQ changes and both were sustained at week 52 [42].

Regarding surgery related to UC, Pica et al. undertook a cohort study to compare HRQoL between UC patients under medical treatment with some others who underwent total colectomy with ileorectal anastomosis (IRA) or IPAA [43]. About $63 \%$ patients in the medical treatment and IRA groups were in remission, whilst $47.9 \%$ patients in the IPAA group reported complications. Their HRQoL survey was composed of four domains (intestinal symptoms, systemic symptoms, emotional and social function), and the only significant difference they found was a worse intestinal-symptoms score in the IRA group. Likewise, no differences were found in the median IBDQ score between IPAA, ileostomy and anti$\mathrm{TNF} \alpha$ treated patients in a later Dutch study $(183,181$ and 181 , respectively, $p=0.27)$. Nevertheless, it was noted that IPAA patients referred further HRQoL deterioration due to bowel symptoms in comparison with the another two groups $(p \leq 0.01)$ [44]. Similarly, a Belgium cohort study showed worse scores reported by IPAA patients compared with anti-TNF $\alpha$ users for 'antidiarrheal medication use', 'stool frequency' and 'perianal skin irritation frequency' domains ( $p<0.001$ for all comparisons). However, it was observed significantly higher general health scores (SF-36) from IPAA patients $(p=0.042)$ and no differences were detected on EQ-5D nor IBD-DI between both groups [45].

\section{Quality of Life Studies in CD}

There are several studies that have shown an association between CD and significant disability and impaired HRQoL. There is a systematic review and meta-analysis that compared HRQoL between CD and UC including physical (2375 participants) and mental scores (2664 participants). The HRQoL scores were shown to be lower in patients with CD compared with UC, but these differences were borderline significant [46].

In the systematic review of Van der Have et al. including 5735 patients with $C D$, the HRQoL was consistently impaired by the occupational disability, number of flares, disease activity, need for hospital admission and use of corticosteroids. Furthermore, the biological treatment had a beneficial impact in the HRQoL. The majority of the studies included in this review employed both generic and disease-specific HRQoL measures, the IBDQ and the SF-36 being the most commonly used [47].

Despite the thinking that HRQoL is mainly related with clinical activity in CD, in a study performed in $92 \mathrm{CD}$ patients in remission, scores on the SF-36 were lower than in the general population of similar age and sex. Age, colonic location and previous surgery was related with worse HRQoL [48].

The effectiveness of different treatments improving HRQoL in patients with CD has been evaluated in clinical trials of new drugs, but also real-life studies (Table 2). Only a few studies have been conducted to assess the impact of thiopurines in HRQoL. A prospective study that included 92 IBD patients $(68 \mathrm{CD})$ who started thiopurines showed a significant impairment HRQoL at week 0 with a basal median IBDQ score of 4.99 (range 2.37-6.84) as compared to patients in remission. In the first year after starting treatment, all dimensions of the IBDQ demonstrate a statistically significant improvement that was more pronounced in those patients receiving steroids at the beginning of the study [49]. In a case-control study it was shown a restoration of HRQOL in patients with CD in remission under thiopurines without differences with healthy controls [50]. 
The impact of anti-TNF in HRQoL in patients with CD is supported by strong evidence based on prospective randomized and real-life studies. In the ACCENT I trial, the authors assessed the effect of infliximab treatment on HRQoL. At the end of the study, at week 54, IBDQ and SF-36 scores in the groups with infliximab demonstrated a substantial improvement. The mean change in the IBDQ at week 54 compared to baseline was 22.1 $(p=0.05)$ in the $5 \mathrm{mg} / \mathrm{kg}$ and $30.2(p=0.001)$ in $10 \mathrm{mg} / \mathrm{kg}$ infliximab maintenance group while it was 8.9 in the placebo group [51].

Other studies confirmed the improvement in HRQoL with infliximab in clinical practice. A retrospective study that included 94 patients with $C D$ who started treatment with infliximab due to moderate-severe active disease, demonstrated an early restoration of HRQoL in 51 patients defined as the overall score of the IBDQ-36 equal or greater than 209 points at week 14 after starting therapy. This early recovery of HRQoL was associated with clinical remission through week 52 [52]. An observational study with 49 patients with CD on infliximab and azathioprine followed for 4 years showed a stable IBDQ-36 in patients on remission with this treatment [53].

In the CHARM study and the open label extension (ADHERE), among 328 patients on adalimumab, more than $50 \%$ achieve IBDQ $\geq 170$ at 3 years from baseline [54]. In a sub-analysis of this study focused on patients with fistulizing disease $(n=48)$ IBDQ remission was achieved in $60 \%$ at 2 years and $52 \%$ at 3 years from baseline [55]. In the CARE trial, 945 patients with CD treated with adalimumab induction and maintenance were evaluated in terms of HRQoL and work productivity. The study included patients who were naïve to biologics and patients who failed infliximab. The mean changes in SIBDQ scores from baseline to weeks 4 and 20 were both statistically significant and they were more pronounced in naïve patients. At Week 20,64\% of naïve patients and 55\% of infliximab non-responders achieved substantial clinical improvement in total activity impairment [56]. The results of the CHOICE trial in 673 patients with CD who started adalimumab support the findings of the CARE study. Clinically meaningful changes in mean SIBDQ total scores at week 24 were seen in naïve patients as well as in the subgroup of infliximab non-responders [57]. In clinical practice, Saro et al. observed, in a prospective study with $126 \mathrm{CD}$ patients, a significant increase in the IBDQ in the first year after starting adalimumab [56.7 (51.6-61.5) to $67.5(60.1-73.6)] p<0.05$ [58].

The HRQoL in patients with CD under vedolizumab was analyzed in the GEMINI 2 and GEMINI long-term safety (LTS) trial. The mean change from baseline for IBDQ and for EQ-5D were $>51$ and $>23$ respectively, in the group under vedolizumab representing a clinically meaningful improvement. The improvement in HRQoL was slightly higher in TNF antagonist-naïve patients than for patients with previous failure to anti-TNF, but the differences were not significant [59]. In relation to real-life data, in an observational study that included 21 patients with $C D$ who started vedolizumab an increase of 8.5 points in IBDQ at week 14 from baseline has been shown [60]. At week 52, in a Swedish observational study that included 169 patients with $\mathrm{CD}$ on vedolizumab, Eriksson et al. identified a significant reduction in the short health scale [61].

The impact of ustekinumab in HRQoL in patients with CD was evaluated in the UNITI trials. In these studies, patients completed IBDQ at baseline and week 8, 20 and 44. An improvement of $\geq 16$ points in IBDQ score at week 8 was achieved in $68.1 \%$ of anti-TNF naïve patients and $54.8 \%$ of patients with previous failure to antiTNF. In the maintenance study this improvement was reached in $67.9 \%$ of patients under ustekinumab $90 \mathrm{mg} \mathrm{q} 8 \mathrm{w}$ at week 44 but only $9.5 \%$ achieved HRQoL normalization (IBDQ $\geq 210$ points) [62]. A real-life study with ustekinumab in $33 \mathrm{CD}$ patients showed a normalization in the IBDQ at week 52 in $18 \%$ of patients. [63].

The effect of intestinal resection in HRQoL was evaluated in many studies. Although surgery remains an important preoperative concern, in the immediately postoperative period, patients generally experience a significant improvement in their HRQoL [64]. In a systematic review including 1108 patients with $\mathrm{CD}$ who underwent intestinal resection, HRQoL improved from two weeks after surgery and has remained stable in the long- 
term [65]. In contrast there are some studies that showed a long-term decrease in the HRQoL of CD patients after surgery [66]; postoperative recurrence, obstructive episodes, the need of new surgery and the number of stools per day were some of factors that contributed to worsening HRQoL [67].

Table 2. IBD treatments that have been shown to improve HRQoL.

\begin{tabular}{|c|c|c|c|c|c|}
\hline Treatment & Study & $\begin{array}{c}\text { Measurement } \\
\text { Tool(s) }\end{array}$ & No. Patients & $\begin{array}{c}\text { HRQoL: Primary } \\
\text { Outcome }\end{array}$ & Results \\
\hline \multirow[b]{2}{*}{ 5-ASA } & $\begin{array}{l}\text { Robinson } \\
\text { et al. [27] }\end{array}$ & $\begin{array}{l}5 \text { disease-specific and } \\
7 \text { general items }\end{array}$ & 374 UC & Yes & $\begin{array}{l}\text { Mesalamine } 2 \mathrm{~g} \text { and } 4 \mathrm{~g} \text { daily was } \\
\text { significantly superior to placebo in } \\
\text { improving each of the } \\
12 \text { HRQoL parameters. }\end{array}$ \\
\hline & $\begin{array}{l}\text { Probert et al. } \\
\text { [28] }\end{array}$ & EQ-5D-3L & 115 UC & No & $\begin{array}{l}\text { The combined (oral + rectal) therapy } \\
\text { group reported a significant } \\
\text { improvement in the 'mobility', 'usual } \\
\text { activity' and 'anxiety/depression' } \\
\text { domains at week } 4 \text {. }\end{array}$ \\
\hline \multirow{3}{*}{ Thiopurines } & $\begin{array}{l}\text { Alruthia et al. } \\
\text { [32] }\end{array}$ & $\begin{array}{l}\text { EQ-5D-3L } \\
\text { EQ-5D-VAS }\end{array}$ & $\begin{array}{c}160 \mathrm{IBD} \\
(56 \% \mathrm{CD}, 44 \% \mathrm{UC})\end{array}$ & Yes & $\begin{array}{l}\text { Patients on AZA presented higher } \\
\text { HRQoL at six-month follow-up } \\
\text { compared with patients on other } \\
\text { treatments ( } \beta=9.35 ; 95 \% \text { CI: } 0.486-18.22 \text {; } \\
\qquad p=0.003) \text {. }\end{array}$ \\
\hline & $\begin{array}{l}\text { Bastida et al. } \\
\text { [49] }\end{array}$ & $\begin{array}{l}\text { SF-36 } \\
\text { IBDQ }\end{array}$ & $\begin{array}{c}92 \text { IBD } \\
(68 \mathrm{CD}, 24 \mathrm{UC})\end{array}$ & Yes & $\begin{array}{l}\text { Compared with baseline, } 68 \text { and } 64 \% \\
\text { patients' scores improved at } 6 \text { and } 12 \\
\text { months, respectively ( } \triangle \text { IBDQ was } 0.86 \\
\text { and } 1.05 \text {, respectively). SF-36 showed a } \\
\text { similar improvement. }\end{array}$ \\
\hline & $\begin{array}{l}\text { Calvet et al. } \\
\text { [50] }\end{array}$ & SF-36 & $\begin{array}{l}33 \mathrm{RCD}^{\mathrm{a}} \\
14 \mathrm{ACD}^{\mathrm{b}} \\
66 \mathrm{HC}^{\mathrm{c}}\end{array}$ & Yes & $\begin{array}{l}\text { SF-36 were } 85 \text { in RCD, } 85 \text { in } \mathrm{HC}(p=1) \\
\text { and } 58.6 \text { in } \mathrm{ACD}(p<0.001 \text { for } \\
\text { comparison with RCD and HC). }\end{array}$ \\
\hline \multirow{3}{*}{ Infliximab } & $\begin{array}{c}\text { Feagan et al. } \\
{[33]}\end{array}$ & $\begin{array}{l}\text { IBDQ } \\
\text { SF-36 }\end{array}$ & $728 \mathrm{UC}$ & No & $\begin{array}{c}\text { IBDQ score improvement was } \\
\text { significantly greater in the IFX } 5 \text { and } \\
10 \mathrm{mg} / \mathrm{kg} \text { groups }(40 \text { and } 36, \text { respectively } \\
p<0.001) \text { vs. placebo }(28) .\end{array}$ \\
\hline & $\begin{array}{l}\text { Silva et al. } \\
\text { [34] }\end{array}$ & IBDQ & 31 UC & Yes & $\begin{array}{l}\text { In IFX group }(n=21) \text {, the IBDQ scores } \\
\text { ranges from } 116.2 \text { at baseline to } 170.75 \\
\text { and } 176.62 \text { at week } 30 \text { and } 54 \\
\text { respectively }(p \leq 0.02)\end{array}$ \\
\hline & $\begin{array}{l}\text { Feagan et al. } \\
{[51]}\end{array}$ & $\begin{array}{l}\text { IBDQ } \\
\text { SF-36 }\end{array}$ & $335 \mathrm{CD}$ & No & $\begin{array}{l}\text { The mean change in the IBDQ at week } \\
54 \text { compared to baseline was } 22.1 \text { in the } \\
5 \mathrm{mg} / \mathrm{kg} \text { and } 30.2 \text { in } 10 \mathrm{mg} / \mathrm{kg} \text { IFX } \\
\text { maintenance group while it was } 8.9 \text { in } \\
\text { the placebo group ( } p \leq 0.05) \text {. SF-36 } \\
\text { changed in the same line. }\end{array}$ \\
\hline \multirow{3}{*}{ Adalimumab } & $\begin{array}{c}\text { Travis et al. } \\
\text { [36] }\end{array}$ & $\begin{array}{c}\text { SIBDQ } \\
\text { EQ-5D-5L } \\
\text { EQ-5D-VAS }\end{array}$ & $463 \mathrm{UC}$ & Yes & $\begin{array}{l}\text { Significant improvements from baseline } \\
\text { to week } 26 \text { were detected on SIBDQ } \\
\text { (mean change } 17.4 \text { ) and EQ5D (index: } \\
0.1 \pm 0.2 ; \text { VAS: } 19.5) \text {. }\end{array}$ \\
\hline & $\begin{array}{l}\text { Louis et al. } \\
\text { [56] }\end{array}$ & SIBDQ & 945 CD & No & $\begin{array}{l}60 \% \text { of IFX-naïve patients and } 47 \% \text { of IFX } \\
\text { primary non-responders reported } \\
\text { clinically significant improvements } \\
\text { ( } \geq 9 \text { points) on SIBDQ. }\end{array}$ \\
\hline & $\begin{array}{l}\text { Saro et al. } \\
\text { [58] }\end{array}$ & $\begin{array}{c}\text { IBDQ } \\
\text { EQ-5D } \\
\text { EQ-5D-VAS }\end{array}$ & $126 \mathrm{CD}$ & Yes & $\begin{array}{l}\text { It has been shown a significant } \\
\text { improvement on the EQ5D from } 0.735 \text { to } \\
\text { 0.797, the EQ5D VAS from } 50.0 \text { to } 80.0 \text {, } \\
\text { and the IBDQ from } 56.7 \text { to } 67.5 \text { ( } p<0.05 \\
\text { for all comparisons). }\end{array}$ \\
\hline Golimumab & $\begin{array}{c}\text { Feagan et al. } \\
\text { [37] }\end{array}$ & $\begin{array}{l}\text { IBDQ } \\
\text { SF-36 }\end{array}$ & 1064 UC & No & $\begin{array}{l}\text { It was determined a significantly greater } \\
\text { improvement from baseline to week } 6 \text { in } \\
\text { GLM vs. placebo groups in IBDQ ( } 27.2 \text { vs. } \\
14.6) \text {, SF-36 PCS ( } 4.14 \text { vs. } 2.46) \text { and MCS } \\
\text { (4.89 vs. } 1.60, p<0.01 \text { for all comparisons). }\end{array}$ \\
\hline
\end{tabular}


Table 2. Cont.

\begin{tabular}{|c|c|c|c|c|c|}
\hline Treatment & Study & $\begin{array}{l}\text { Measurement } \\
\text { Tool(s) }\end{array}$ & No. Patients & $\begin{array}{l}\text { HRQoL: Primary } \\
\text { Outcome }\end{array}$ & Results \\
\hline \multirow{5}{*}{ Vedolizumab } & $\begin{array}{c}\text { Feagan et al. } \\
\text { [38] }\end{array}$ & $\begin{array}{c}\text { IBDQ } \\
\text { SF-36 } \\
\text { EQ-5D-3L } \\
\text { ED-5D-VAS }\end{array}$ & $373 \mathrm{UC}$ & No & $\begin{array}{l}\text { Patients on VDZ reported significantly } \\
\text { greater improvements in IBDQ and } \\
\text { EQ5D-VAS scores. For EQ-5D utility } \\
\text { score, only the VDZ every } 4 \text { weeks group } \\
\text { showed a significant difference from } \\
\text { placebo. At week 52, more patients on } \\
\text { VDZ met the minimal clinically } \\
\text { meaningful difference thresholds for } \\
\text { IBDQ, SF-36 physical component and } \\
\text { EQ5D-VAS scores. }\end{array}$ \\
\hline & $\begin{array}{l}\text { Loftus et al. } \\
\text { [39] }\end{array}$ & IBDQ & $\begin{array}{l}769 \text { UC (383 VDZ, } \\
386 \text { ADA) }\end{array}$ & No & $\begin{array}{l}\text { At week } 52 \text {, clinically important IBDQ } \\
\text { improvement was detected in a greater } \\
\text { proportion of VDZ treated patients } \\
\text { compared with ADA treated ones ( } 52.0 \% \\
\text { vs. } 42.2 \% \text { ). Likewise, } 50.1 \% \text { (VDZ) vs. } \\
40.4 \% \text { (ADA) of patients achieved } \\
\text { IBDQ remission. }\end{array}$ \\
\hline & $\begin{array}{l}\text { Vermiere } \\
\text { et al. [59] }\end{array}$ & $\begin{array}{l}\text { IBDQ } \\
\text { EQ5D-VAS } \\
\text { SF-36 }\end{array}$ & $1349 \mathrm{CD}$ & No & $\begin{array}{l}\text { At week } 80 \text {, the mean changes from } \\
\text { baseline HRQL scores were }>51 \text { for IBDQ, } \\
>23 \text { for EQ-5D VAS, }>9 \text { for SF-36 PCS and } \\
>10 \text { for SF- } 36 \text { MCS. }\end{array}$ \\
\hline & $\begin{array}{l}\text { Parkes et al. } \\
\text { [60] }\end{array}$ & SIBDQ & $\begin{array}{c}61 \mathrm{IBD} \\
(21 \mathrm{CD}, 40 \mathrm{UC})\end{array}$ & No & $\begin{array}{l}\text { SIBDQ score increased by } 8.5 \text { and } \\
10.2 \text { points in CD and UC patients, } \\
\text { respectively, at week } 14 .\end{array}$ \\
\hline & $\begin{array}{l}\text { Eriksson } \\
\text { et al. [61] }\end{array}$ & SHS & $169 \mathrm{CD}$ & No & $\begin{array}{l}\text { It has been seen a significant decreased of } \\
\text { the SHS score at week } 52(n=68 ; p<0.001)\end{array}$ \\
\hline \multirow{3}{*}{ Ustekinumab } & $\begin{array}{l}\text { Sandborn } \\
\text { et al. [41] }\end{array}$ & $\begin{array}{l}\text { IBDQ } \\
\text { SF-36 }\end{array}$ & $284 \mathrm{UC}$ & No & $\begin{array}{l}55.6 \% \text { of patients who had been treated } \\
\text { with USK were in IBDQ remission. } \\
\text { Regarding the SF- } 36,50.0 \% \text { and } 45.1 \% \text { of } \\
\text { patients had a clinically meaningful } \\
\text { improvement in the PCS and the } \\
\text { MCS, respectively. }\end{array}$ \\
\hline & $\begin{array}{l}\text { Sands et al. } \\
\text { [62] }\end{array}$ & $\begin{array}{l}\text { IBDQ } \\
\text { SF-36 }\end{array}$ & $1368 \mathrm{CD}$ & No & $\begin{array}{l}\text { A clinically meaningful improvement in } \\
\text { IBDQ score at week } 8 \text { was achieved in } \\
68.1 \% \text { of anti-TNF naïve patients and } \\
54.8 \% \text { of patients with previous failure to } \\
\text { antiTNF. Similarly, greater improvements } \\
\text { in SF-36 in the USK group have } \\
\text { been determined. }\end{array}$ \\
\hline & $\begin{array}{l}\text { Marquès } \\
\text { et al. [63] }\end{array}$ & IBDQ & $33 \mathrm{CD}$ & Yes & $\begin{array}{c}18 \% \text { achieved IBDQ normalization at } \\
\text { week } 52 .\end{array}$ \\
\hline Tofacitinib & $\begin{array}{l}\text { Panés et al. } \\
{[42]}\end{array}$ & $\begin{array}{l}\text { IBDQ } \\
\text { SF-36 }\end{array}$ & $\begin{array}{c}1161 \mathrm{UC} \\
\text { (induction) } \\
593 \text { UC (sustain) }\end{array}$ & No & $\begin{array}{l}\text { In OCTAVE induction } 1 \text { and } 2, \text { mean IBDQ } \\
\text { changes from baseline to week } 8 \text { was } 40.7 \\
\text { and } 44.6 \text { with TFC } 10 \mathrm{mg} \text { twice daily } \\
\text { versus } 21 \text { and } 25 \text { with placebo, respectively } \\
(p<0.001) \text {. Mean SF- } 36 \text { changes were } \\
\text { comparable with the IBDQ changes and } \\
\text { both were sustained at week } 52\end{array}$ \\
\hline \multirow{2}{*}{$\begin{array}{l}\text { Surgery } \\
\text { (intestinal } \\
\text { resection) }\end{array}$} & Wright et al. & $\begin{array}{l}\text { IBDQ } \\
\text { SF-36 }\end{array}$ & $174 \mathrm{CD}$ & No & $\begin{array}{l}\text { A significant improvement has been } \\
\text { observed at } 6 \text { months postoperatively } \\
\text { compared to preoperatively in PCS ( } 68 \text { vs. } \\
\text { 40), MCS ( } 68 \text { vs. } 44 \text { ) and IBDQ (171 vs. } \\
\text { 125; } p<0.001 \text { for all comparisons). }\end{array}$ \\
\hline & Ha et al. [65] & $\begin{array}{l}5 \text { generic tools } \\
3 \text { disease-specific } \\
\text { tools }\end{array}$ & $1108 \mathrm{CD}$ & Yes & $\begin{array}{l}\text { Both generic and disease-specific tools } \\
\text { showed an improvement in HRQoL from } \\
2 \text { weeks after intestinal resection for up } \\
\text { to } 5 \text { years. }\end{array}$ \\
\hline
\end{tabular}

AZA: azathioprine. IFX: infliximab. GLM: golimumab. VDZ: vedolizumab. ADA: adalimumab. USK: ustekinumab. TFC: tofacitinib. ${ }^{a}$ Remission Crohn's disease. ${ }^{b}$ Active Crohn's disease. ${ }^{\mathrm{c}}$ Healthy controls. 
The LIRIC study (a randomized trial that compared laparoscopic ileocecal resection with infliximab in patients with CD) showed similar results in terms of HRQoL in both groups. One hundred forty-three patients with inflammatory ileocecal CD who had previously failed conventional treatment were randomized to infliximab or ileocecal resection. The mean IBDQ score at 1 year was 178.1 (95\% CI 171.1-185) in the surgery group and 172 (96\% CI 164.3-179.6) in the infliximab group. The authors concluded that laparoscopic resection had similar HRQoL outcomes to treatment with infliximab and could be a reasonable option in this group of patients [68].

\section{Why should HRQoL Be a Target in IBD?}

There are scarce studies that have studied the relationship between potential targets in IBD and HRQoL. In a multicenter study performed in Spain which included 115 IBD patients, it was observed that among patients who achieved mucosal healing, $82 \%$ in $C D$ and $78 \%$ in UC could normalize their HRQoL [69].

Psychological aspects related to chronic conditions, like anxiety and depression, have a close relationship with HRQoL [70]. In a cross-sectional prospective study performed in 875 consecutive IBD patients, all completed the Hospital Anxiety and Depression Scale (HADS) questionnaire, the Perceived Stress Scale (PSS) questionnaire and the COPE questionnaire to measure psychological alteration. In order to assess HRQoL, the SF-36 and the IBDQ-36 questionnaires were also completed. Authors concluded that high levels of anxiety, depression and stress were found to be associated with low levels in all quality of life measurements [25]. These results made some authors think about the need not only to have the physical component of HRQoL as an endpoint in IBD, but to go further and also consider psychological remission as a future endpoint in IBD too [71].

The importance of HRQoL as endpoint for new drugs is going to increase in the coming years. There is no doubt that for IBD patients it is essential to normalize their HRQoL for their daily life. We as physicians have to realize that patients with normal HRQoL are going to have a better prognosis and evolution of their disease.

Author Contributions: Study concept and design: M.B.-d.A. Drafting of the manuscript: M.B.-d.A., I.B.-R., R.F.-I., C.C.-S. Critical revision of the manuscript for important intellectual content: M.B.d.A., I.B.-R., R.F.-I., C.C.-S. Approval of the final manuscript: M.B.-d.A., I.B.-R., R.F.-I. and C.C.-S. Guarantor of the article: M.B.-d.A. All authors have read and agreed to the published version of the manuscript.

Funding: This research received no external funding.

Institutional Review Board Statement: Not applicable.

Informed Consent Statement: Not applicable.

Data Availability Statement: Not applicable.

Conflicts of Interest: C.C.-S. has served as a speaker for or has received research funding from MSD, Jansen and Takeda. R.F.-I. has served as a speaker, consultant and advisory member for or has received research funding from MSD, AbbVie, Janssen, Takeda, Pfizer, Ferring, Faes Farma, Shire Pharmaceuticals, Falk Pharma, Chiesi, Gebro Pharma, Adacyte, Palex and Casenrecordati. I.B.-R. has served as a speaker for MSD, Janssen, Pfizer. MBA has served as a speaker, consultant and advisory member for or has received research funding from MSD, AbbVie, Janssen, Kern Pharma, Celltrion, Takeda, Gillead, Celgene, Pfizer, Ferring, Faes Farma, Shire Pharmaceuticals, Falk Pharma, Chiesi, Gebro Pharma, Adacyte and Vifor Pharma.

\section{References}

1. Schwartzmann, L. Calidad de vida Relacionada con la Salud: Aspectos Conceptuales. Cienc. Enfermería 2003, 9, 9-21. [CrossRef]

2. Childs, A. World Health Organization: Constitution of the World Health Organization; WHO: Geneva, Swizerland, 1947; Volume 1, pp. 29-43.

3. Mayo, N. (Ed.) Dictionary of Quality of Life and Health Outcomes Measurement, 1st ed.; International Society for Quality of Life Research (ISOQOL): Milwaukee, WI, USA, 2015.

4. Torrance, G.W. Utility Approach to Measuring Health-Related Quality of Life. J. Chronic. Dis. 1987, 40, 593-603. [CrossRef] 
5. Knowles, S.R.; Graff, L.A.; Wilding, H.; Hewitt, C.; Keefer, L.; Mikocka-Walus, A. Quality of Life in Inflammatory Bowel Disease: A Systematic Review and Meta-analyses-Part I. Inflamm. Bowel. Dis. 2018, 24, 742-751. [CrossRef]

6. Peyrin-Biroulet, L.; Sandborn, W.; Sands, B.E.; Reinisch, W.; Bemelman, W.; Bryant, R.V.; D’Haens, G.; Dotan, I.; Dubinsky, M.; Feagan, B.; et al. Selecting Therapeutic Targets in Inflammatory Bowel Disease (STRIDE): Determining Therapeutic Goals for Treat-to-Target. Am. J. Gastroenterol. 2015, 110, 1324-1338. [CrossRef]

7. Turner, D.; Ricciuto, A.; Lewis, A.; D’Amico, F.; Dhaliwal, J.; Griffiths, A.M.; Bettenworth, D.; Sandborn, W.J.; Sands, B.E.; Reinisch, W.; et al. STRIDE-II: An Update on the Selecting Therapeutic Targets in Inflammatory Bowel Disease (STRIDE) Initiative of the International Organization for the Study of IBD (IOIBD): Determining Therapeutic Goals for Treat-to-Target strategies in IBD. Gastroenterology 2021, 160. [CrossRef] [PubMed]

8. Chen, X.L.; Zhong, L.H.; Wen, Y.; Liu, T.W.; Li, X.Y.; Hou, Z.K.; Hu, Y.; Mo, C.W.; Liu, F.B. Inflammatory Bowel Disease-Specific Health-Related Quality of Life Instruments: A Systematic Review of Measurement Properties. Health Qual. Life Outcomes 2017, 15, 177. [CrossRef]

9. Van Andel, E.M.; Koopmann, B.D.M.; Crouwel, F.; Noomen, C.G.; de Boer, N.K.H.; van Asseldonk, D.P.; Mokkink, L.B. Systematic review of development and content validity of patient-reported outcome measures in inflammatory bowel disease: Do we measure what we measure? J. Crohns Colitis 2020, 14, 1299-1315. [CrossRef] [PubMed]

10. Yarlas, A.; Maher, S.; Bayliss, M.; Lovley, A.; Cappelleri, J.C.; Bushmakin, A.G.; DiBonaventura, M.D. The Inflammatory Bowel Disease Questionnaire in Randomized Controlled Trials of Treatment for Ulcerative Colitis: Systematic Review and Meta-Analysis. J. Patient Cent. Res. Rev. 2020, 7, 189-205. [CrossRef] [PubMed]

11. Häuser, W.; Dietz, N.; Grandt, D.; Steder-Neukamm, U.; Janke, K.-H.; Stein, U.; Stallmach, A. Validation of the Inflammatory Bowel Disease Questionnaire IBDQ-D, German Version, for Patients with Ileal Pouch Anal Anastomosis for Ulcerative Colitis. Z. Gastroenterol. 2004, 42, 131-139. [CrossRef] [PubMed]

12. Wilburn, J.; McKenna, S.P.; Twiss, J.; Kemp, K.; Campbell, S. Assessing quality of life in Crohn's disease: Development and validation of the Crohn's Life Impact Questionnaire (CLIQ). Qual. Life Res. 2015, 24, 2279-2288. [CrossRef]

13. Adegbola, S.O.; Dibley, L.; Sahnan, K.; Wade, T.; Verjee, A.; Sawyer, R.; Mannick, S.; McCluskey, D.; Bassett, P.; Yassin, N.; et al. Development and initial psychometric validation of a patient-reported outcome measure for Crohn's perianal fistula: The Crohn's Anal Fistula Quality of Life (CAF-QoL) Scale. Gut 2020, 1-8. [CrossRef]

14. Otley, A.; Smith, C.; Nicholas, D.; Munk, M.; Avolio, J.; Sherman, P.; Griffiths, A.M. The IMPACT questionnaire: A valid measure of health-related quality of life in pediatric inflammatory bowel disease. J. Pediatr. Gastroenterol. Nutr. 2002, 35, 557-563. [CrossRef] [PubMed]

15. Ware, J.; Sherbourne, C. The MOS 36-item short-form health survey (SF-36). I. Conceptual framework and item selection. Med. Care 1992, 30, 473-483. [CrossRef] [PubMed]

16. EuroQol Group. EuroQol-A new facility for the measurement of health-related quality of life. Health Policy N. Y. 1990, 16, 199-208. [CrossRef]

17. Kaplan, R.M.; Anderson, J.P.; Wu, A.W.; Mathews, W.C.; Kozin, F.; Orenstein, D. The quality of well-being scale: Applications in AIDS, cystic fibrosis, and arthritis. Med. Care 1989, 27, S27-S43. [CrossRef] [PubMed]

18. Feeny, D.; Furlong, W.; Boyle, M.; Torrance, G.W. Multi-Attribute Health Status Classification Systems: Health Utilities Index. Pharmacoeconomics 1995, 7, 490-502. [CrossRef]

19. Haraldstad, K.; Wahl, A.; Andenæs, R.; Andersen, J.R.; Andersen, M.H.; Beisland, E.; Borge, C.R.; Engebretsen, E.; Eisemann, M.; Halvorsrud, L.; et al. A systematic review of quality of life research in medicine and health sciences. Qual. Life Res. 2019, 28, 2641-2650. [CrossRef]

20. Hoivik, M.L.; Moum, B.; Solberg, I.C.; Cvancarova, M.; Hoie, O.; Vatn, M.H.; Bernklev, T. Health-Related Quality of Life in Patients with Ulcerative Colitis After a 10-year Disease Course: Results from the IBSEN Study. Inflamm. Bowel. Dis. 2012, 18, 1540-1549. [CrossRef]

21. Bitton, A.; Sewitch, M.J.; Peppercorn, M.A.; Edwardes, M.D.D.B.; Shah, S.; Ransil, B.; Locke, S.E. Psychosocial Determinants of Relapse in Ulcerative Colitis: A Longitudinal Study. Am. J. Gastroenterol. 2003, 98, 2203-2208. [CrossRef]

22. Han, S.W.; McColl, E.; Barton, J.R.; James, P.; Steen, I.N.; Welfare, M.R. Predictor's of quality of life in ulcerative colitis: The importance of symptoms and illness representations. Inflamm. Bowel. Dis. 2005, 11, 24-34. [CrossRef]

23. Verma, S.; Giaffer, M.H. Does better disease-related education improve quality of life? A survey of IBD patients. Dig. Dis. Sci. 2001, 46, 865-869. [CrossRef] [PubMed]

24. Rasmussen, B.; Haastrup, P.; Wehberg, S.; Kjeldsen, J.; Waldorff, F.B. Predictors of health-related quality of life in patients with moderate to severely active ulcerative colitis receiving biological therapy. Scand. J. Gastroenterol. 2020, 55, 656-663. [CrossRef]

25. Iglesias-Rey, M.; Acosta, M.B.-D.; Caamano-Isorna, F.; Rodríguez, I.V.; Ferreiro, R.; Lindkvist, B.; González, A.L.; DominguezMunoz, J.E. Psychological factors are associated with changes in the health-related quality of life in inflammatory bowel disease. Inflamm. Bowel. Dis. 2014, 20, 92-102. [CrossRef] [PubMed]

26. López-Sanromán, A.; Carpio, D.; Calvet, X.; Romero, C.; Cea-Calvo, L.; Juliá, B.; Argüelles-Arias, F. Perceived Emotional and Psychological Impact of Ulcerative Colitis on Outpatients in Spain: UC-LIFE Survey. Dig. Dis. Sci. 2017, 62, 207-216. [CrossRef]

27. Robinson, M.; Hanauer, S.; Hoop, R.; Zbrozek, A.; Wilkinson, C. Mesalamine capsules enhance the quality of life for patients with ulcerative colitis. Aliment. Pharmacol. Ther. 1994, 8, 27-34. [CrossRef] [PubMed] 
28. Probert, C.S.; Dignass, A.U.; Lindgren, S.; Pool, M.O.; Marteau, P. Combined oral and rectal mesalazine for the treatment of mild-to-moderately active ulcerative colitis: Rapid symptom resolution and improvements in quality of life. J. Crohns Colitis 2014, 8, 200-207. [CrossRef] [PubMed]

29. Bernklev, T.; Jahnsen, J.; Schulz, T.; Sauar, J.; Lygren, I.; Henriksen, M.; Stray, N.; Øystein, K.; Aadland, E.; Vatn, M.; et al. Course of disease, drug treatment and health-related quality of life in patients with inflammatory bowel disease 5 years after initial diagnosis. Eur. J. Gastroenterol. Hepatol. 2005, 17, 1037-1045. [CrossRef] [PubMed]

30. Rivera Sequeiros, A.; Gil García, E.; Chillón Martinez, R. N800 Statistical comparison of predictors of quality of life in inflammatory bowel disease. J. Crohns Colitis 2017, 11 (Suppl. S1). [CrossRef]

31. Ghosh, S.; Mitchell, R. Impact of inflammatory bowel disease on quality of life: Results of the European Federation of Crohn's and Ulcerative Colitis Associations (EFCCA) patient survey. J. Crohns Colitis 2007, 1, 10-20. [CrossRef]

32. Alruthia, Y.; Alsharif, W.; Almuaythir, G.; Alrasheed, H.; Alharbi, O.; Azzam, N.; Almadi, M.; Saeed, M.; Hajkhder Mullaissa, B.; Aljebreen, A. P444 The impact of azathioprine on inflammatory bowel disease patients' overall health-related quality of life: A single-centre retrospective cohort study. J. Crohns Colitis 2020, 14 (Suppl. S1), S400-S401. [CrossRef]

33. Feagan, B.G.; Reinisch, W.; Rutgeerts, P.; Sandborn, W.J.; Yan, S.; Eisenberg, D.; Bala, M.; Johanns, J.; Olson, A.; Hanauer, S.B. The effects of infliximab therapy on health-related quality of life in ulcerative colitis patients. Am. J. Gastroenterol. 2007, 102, 794-802. [CrossRef]

34. Silva, R.; Baima, J.; Bissoli, G.; Farinelli, E.; Sibia, C.; Barros, J.; Biondi, R.; Renosto, F.; Hossne, R.; Sassaki, L. N816 Anti-TNF therapy improves the quality of life in patients with ulcerative colitis. J. Crohns Colitis 2017, 11 (Suppl. S1), S498-S499. [CrossRef]

35. Sandborn, W.J.; van Assche, G.; Reinisch, W.; Colombel, J.; D’Haens, G.; Wolf, D.C.; Kron, M.; Tighe, M.B.; Lazar, A.; Thakkar, R.B. Adalimumab induces and maintains clinical remission in patients with moderate-to-severe ulcerative colitis. Gastroenterology 2012, 142. [CrossRef]

36. Travis, S.; Feagan, B.G.; Peyrin-Biroulet, L.; Panaccione, R.; Danese, S.; Lazar, A.; Robinson, A.M.; Petersson, J.; Pappalardo, B.L.; Bereswill, M.; et al. Effect of adalimumab on clinical outcomes and health-related quality of life among patients with ulcerative colitis in a clinical practice setting: Results from InspirADA. J. Crohns Colitis 2017, 11, 1317-1325. [CrossRef]

37. Feagan, B.; Gibson, P.; Marano, C.; Strauss, R.; Han, C.; Johanns, J.; Zhang, H.; Guzzo, C.; Colombel, J.-F.; Reinisch, W.; et al. P225 Impact of subcutaneously administered golimumab on disease specific and generic health-related quality of life in patients with moderately to severely active ulcerative colitis: Results from PURSUIT-SC induction. J. Crohns Colitis 2013, 7 (Suppl. S1), S99-S100. [CrossRef]

38. Feagan, B.G.; Patel, H.; Colombel, J.-F.; Rubin, D.T.; James, A.; Mody, R.; Lasch, K. Effects of vedolizumab on health-related quality of life in patients with ulcerative colitis: Results from the randomised GEMINI 1 trial. Aliment. Pharmacol. Ther. 2017, 45, 264-275. [CrossRef]

39. Loftus, E.V.; Schreiber, S.W.; Danese, S.; Peyrin-Biroulet, L.; Colombel, J.F.; Sands, B.E.; Wang, S.; Chen, J.; Lirio, R.A. DOP24 Patient-reported health-related quality-of-life outcomes with vedolizumab vs. adalimumab treatment of ulcerative colitis: Results of the VARSITY trial. J. Crohns Colitis 2020, 14 (Suppl. S1), S063. [CrossRef]

40. Sands, B.E.; Sandborn, W.J.; Panaccione, R.; O’Brien, C.D.; Zhang, H.; Johanns, J.; Adedokun, O.J.; Li, K.; Peyrin-Biroulet, L.; Van Assche, G.; et al. Ustekinumab as Induction and Maintenance Therapy for Ulcerative Colitis. N. Engl. J. Med. 2019, 381, 1201-1214. [CrossRef]

41. Sandborn, W.J.; Rowbotham, D.S.; Leong, R.W.L.; Han, C.; Zhou, Y.; Zhang, H.; Johanns, J.; Marano, C.; Danese, S. DOP56 Ustekinumab maintained clinically meaningful improvement in health-related quality of life in patients with moderate to severe ulcerative colitis: Results from the UNIFI long-term extension. J. Crohns Colitis 2020, 14 (Suppl. S1), S094-S095. [CrossRef]

42. Panés, J.; Vermeire, S.; Lindsay, J.O.; Sands, B.E.; Su, C.; Friedman, G.; Zhang, H.; Yarlas, A.; Bayliss, M.; Maher, S.; et al. Tofacitinib in Patients with Ulcerative Colitis: Health-Related Quality of Life in Phase 3 Randomised Controlled Induction and Maintenance Studies. J. Crohns Colitis 2018, 12, 145-156. [CrossRef]

43. Pica, R.; Cassieri, C.; Pronio, A.M.; Zippi, M.; Avallone, E.V.; Montesani, C.; Occhigrossi, G.; Paoluzi, P. Quality of life in ulcerative colitis patients treated medically versus patients undergoing surgery. Eur. Rev. Med. Pharmacol. Sci. 2014, 18, 693-698.

44. Van Der Valk, M.E.; Mangen, M.-J.J.; Severs, M.; Van Der Have, M.; Dijkstra, G.; Van Bodegraven, A.A.; Fidder, H.H.; De Jong, D.J.; Pierik, M.; Van Der Woude, C.J.; et al. Comparison of costs and quality of life in ulcerative colitis patients with an ileal pouch-anal anastomosis, ileostomy and anti-TNF $\alpha$ therapy. J. Crohns Colitis 2015, 9, 1016-1023. [CrossRef] [PubMed]

45. Van Gennep, S.; Sahami, S.; Buskens, C.J.; Brink, G.R.V.D.; Ponsioen, C.Y.; D’Hoore, A.; Overstraeten, A.D.B.V.; Van Assche, G.; Ferrante, M.; Vermeire, S.; et al. Comparison of health-related quality of life and disability in ulcerative colitis patients following restorative proctocolectomy with ileal pouch-anal anastomosis versus anti-tumor necrosis factor therapy. Eur. J. Gastroenterol. Hepatol. 2017, 29, 338-344. [CrossRef] [PubMed]

46. Knowles, S.R.; Keefer, L.; Wilding, H.; Hewitt, C.; Graff, L.; Mikocka-Walus, A. Quality of Life in Inflammatory Bowel Disease: A Systematic Review and Meta-analyses-Part II. Inflamm. Bowel. Dis. 2018, 24, 966-976. [CrossRef] [PubMed]

47. Van Der Have, M.; Van Der Aalst, K.S.; Kaptein, A.A.; Leenders, M.; Siersema, P.D.; Oldenburg, B.; Fidder, H.H. Determinants of health-related quality of life in Crohn's disease: A systematic review and meta-analysis. J. Crohns Colitis 2014, 8, 93-106. [CrossRef] 
48. Iglesias, M.; Vázquez, I.; De Acosta, M.B.; Figueiras, A.; Nieto, L.; Piñeiro, M.; Gómez, R.; Lorenzo, A.; Dominguez-Munoz, J.E. Health related quality of life in patients with Cohn's disease in remission. Rev. Esp. Enfermedades Dig. 2010, 102, 624-630. [CrossRef]

49. Bastida, G.; Nos, P.; Aguas, M.; Beltrán, B.; Iborra, M.; Ortiz, V.; Garrigues, V.; Estevan, R.; Ponce, J. The effects of thiopurine therapy on health-related quality of life in Inflammatory Bowel Disease patients. BMC Gastroenterol. 2010, 10. [CrossRef]

50. Calvet, X.; Gallardo, O.; Coronas, R.; Casellas, F.; Montserrat, A.; Torrejon, A.; Vergara, M.; Campo, R.; Brullet, E. Remission on thiopurinic immunomodulators normalizes quality of life and psychological status in patients with Crohn's disease. Inflamm. Bowel. Dis. 2006, 12, 692-696. [CrossRef]

51. Feagan, B.G.; Yan, S.; Bala, M.; Bao, W.; Lichtenstein, G.R. The Effects of Infliximab Maintenance Therapy on Health-Related Quality of Life. Am. J. Gastroenterol. 2003, 98, 2232-2238. [CrossRef]

52. Herrera-Deguise, C.; Casellas, F.; Robles, V.; Navarro, E.; Borruel, N. Predictive value of early restoration of quality of life in Crohn's disease patients receiving antitumor necrosis factor agents. J. Gastroenterol. Hepatol. 2015, 30, 286-291. [CrossRef] [PubMed]

53. Casellas, F.; Rodrigo, L.; Niño, P.; Pantiga, C.; Riestra, S.; Malagelada, J.-R. Sustained improvement of health-related quality of life in Crohn's disease patients treated with infliximab and azathioprine for 4 years. Inflamm. Bowel. Dis. 2007, 13, 1395-1400. [CrossRef]

54. Loftus, E.; Colombel, J.; Panaccione, R.; Rubin, D.; Chen, N.; Chao, J.; Mulani, P. P008-Adalimumab sustains quality-of-life improvements in patients with Crohn's disease: 3-year data from CHARM. J. Crohns Colitis 2009, 3, S14. [CrossRef]

55. Schwartz, D.; Colombel, J.; Panaccione, R.; Feagan, B.; Kamm, M.; Chen, N.; Chao, J.; Mulani, P. P006-Sustainability of adalimumab in improving the quality of life of patients with fistulizing Crohn's disease: 3-year data from CHARM. J. Crohns Colitis 2009, 3, S13. [CrossRef]

56. Louis, E.; Löfberg, R.; Reinisch, W.; Camez, A.; Yang, M.; Pollack, P.F.; Chen, N.; Chao, J.; Mulani, P.M. Adalimumab improves patient-reported outcomes and reduces indirect costs in patients with moderate to severe Crohn's disease: Results from the CARE trial. J. Crohns Colitis 2013, 7, 34-43. [CrossRef]

57. Lichtiger, S.; Binion, D.G.; Wolf, D.C.; Present, D.H.; Bensimon, A.G.; Wu, E.; Yu, A.P.; Cardoso, A.T.; Chao, J.; Mulani, P.M.; et al The CHOICE trial: Adalimumab demonstrates safety, fistula healing, improved quality of life and increased work productivity in patients with Crohns disease who failed prior infliximab therapy. Aliment. Pharmacol. Ther. 2010, 32, 1228-1239. [CrossRef]

58. Saro, C.; Ceballos, D.; Muñoz, F.; De La Coba, C.; Aguilar, M.D.; Lázaro, P.; García-Sánchez, V.; Hernandez, M.; Barrio, J.; De Francisco, R.; et al. Clinical status, quality of life, and work productivity in Crohn's disease patients after one year of treatment with adalimumab. Rev. Esp. Enferm. Dig. 2017, 109, 122-129. [CrossRef]

59. Vermeire, S.; Loftus, E.V.; Colombel, J.-F.; Feagan, B.G.; Sandborn, W.J.; Sands, B.E.; Danese, S.; D’Haens, G.R.; Kaser, A.; Panaccione, R.; et al. Long-term Efficacy of Vedolizumab for Crohns Disease. J. Crohns Colitis 2016, 11, jjw176. [CrossRef] [PubMed]

60. Parkes, G.; Akbar, A.; Beales, I.; Buckley, M.; Creed, T.; Din, S.; Fraser, A.; Plevris, N.; Meadowcroft, S.; Owen, G.; et al. P713 Effects of vedolizumab on health-related quality of life, work productivity and patient concerns in patients with ulcerative colitis and Crohn's disease in the UK and Ireland: OCTAVO cohort 2. J. Crohns Colitis 2020, 14 (Suppl. S1), S575-S576. [CrossRef]

61. Eriksson, C.; Rundquist, S.; Lykiardopoulos, V.; Karlén, P.; Grip, O.; Söderman, C.; Almer, S.; Hertervig, E.; Gunnarsson, J.; Malmgren, C.; et al. P758 Clinical effectiveness of vedolizumab: Interim analysis of the Swedish observational study on vedolizumab assessing effectiveness and healthcare resource utilisation in patients with Crohn's disease (SVEAH CD). J. Crohns Colitis 2018, 12 (Suppl. S1), S494-S495. [CrossRef]

62. E Sands, B.; Han, C.; Gasink, C.; Jacobstein, D.; Szapary, P.; Gao, L.-L.; Lang, Y.; Targan, S.; Sandborn, W.J.; Feagan, B.G. The Effects of Ustekinumab on Health-related Quality of Life in Patients With Moderate to Severe Crohn's Disease. J. Crohns Colitis 2018, 12, 883-895. [CrossRef]

63. Marquès Camí, M.; Robles Alonso, V.; Borruel Sainzn, N.; Herrera de Guise, C.; Mayorga Ayala, L.; Casellas Jordá, F. Normalization of long-term quality of life in Crohn's disease patients receiving ustekinumab. Rev. Española Enferm. Dig. 2020. [CrossRef] [PubMed]

64. Wright, E.K.; Kamm, M.A.; De Cruz, P.; Hamilton, A.L.; Ritchie, K.J.; Krejany, E.O.; Gorelik, A.; Liew, D.; Prideaux, L.; Lawrance, I.C.; et al. Effect of Intestinal Resection on Quality of Life in Crohn's Disease. J. Crohns Colitis 2015, 9, 452-462. [CrossRef] [PubMed]

65. Ha, F.J.; Thong, L.; Khalil, H. Quality of Life after Intestinal Resection in Patients with Crohn Disease: A Systematic Review. Dig. Surg. 2017, 34, 355-363. [CrossRef]

66. Thaler, K.; Dinnewitzer, A.; Oberwalder, M.; Weiss, E.G.; Nogueras, J.J.; Wexner, S.D. Assessment of long-term quality of life after laparoscopic and open surgery for Crohn's disease. Color. Dis. 2005, 7, 375-381. [CrossRef] [PubMed]

67. Scarpa, M.; Ruffolo, C.; D’incà, R.; Filosa, T.; Bertin, E.; Ferraro, S.; Polese, L.; Martin, A.; Sturniolo, G.C.; Frego, M.; et al. Health-related quality of life after ileocolonic resection for Crohn's disease: Long-term results. Inflamm. Bowel. Dis. 2007, 13, 462-469. [CrossRef]

68. Ponsioen, C.Y.; de Groof, E.J.; Eshuis, E.J.; Gardenbroek, T.J.; Bossuyt, P.M.M.; Hart, A.; Warusavitarne, J.; Buskens, C.J.; van Bodegraven, A.A.; Brink, M.A.; et al. Laparoscopic ileocaecal resection versus infliximab for terminal ileitis in Crohn's disease: A randomised controlled, open-label, multicentre trial. Lancet Gastroenterol. Hepatol. 2017, 2, 785-792. [CrossRef] 
69. Casellas, F.; De Acosta, M.B.; Iglesias, M.; Robles, V.; Nos, P.; Aguas, M.; Riestra, S.; De Francisco, R.; Papo, M.; Borruel, N. Mucosal healing restores normal health and quality of life in patients with inflammatory bowel disease. Eur. J. Gastroenterol. Hepatol. 2012, 24, 762-769. [CrossRef]

70. Nazarian, A.; Bishay, K.; Gholami, R.; Scaffidi, M.A.; Khan, R.; Cohen-Lyons, D.; Griller, N.; Satchwell, J.B.; Baker, J.P.; Grover, S.C.; et al. Factors Associated with Poor Quality of Life in a Canadian Cohort of Patients with Inflammatory Bowel Disease: A Cross-sectional Study. J. Can. Assoc. Gastroenterol. 2021, 4, 91-96. [CrossRef]

71. Barreiro-De Acosta, M.; Gisbert, J.P. Letter: Psychological remission-A future endpoint in inflammatory bowel disease? Aliment. Pharmacol. Ther. 2014, 39, 1436. [CrossRef] 